\title{
A novel method to find out sensory neuron tracts in the Drosophila brain
}

\author{
Chao-Chun Chuang
}

From 24th Annual Computational Neuroscience Meeting: CNS*2015

Prague, Czech Republic. 18-23 July 2015

How receptions of sensory inputs information turn into perceptions in our brain? To address these questions, we proposed method reconstructs the neuronal tracts by applying the shortest path graph algorithm between functional regions in the Drosophila brain. With these neuronal tracts, we analyze and draw a network diagram of projection neurons (PNs) relaying sensory input to higher brain centers in the Drosophila brain. Drosophila is a widely used genetic model system for understanding human biology $[1,2]$. While distinctively different in gross anatomy, insect brains and mammalian brains are both made of neural circuits with a cohort of similar gene expression governing the basic demands of life.
With this network diagram, numerous unexpected local networks and inter-regional pathways were found from our initial analysis of sensory systems including olfactory, gustatory, auditory, and vision circuits [3].

\section{Conclusion}

The network diagram shows hierarchical structure, smallworld characteristics, and is composed of functional modules corresponding to the sensory modalities. This ultimate goal of such an atlas is to identify connectivity between neurons for understanding the function/circuit relationships.

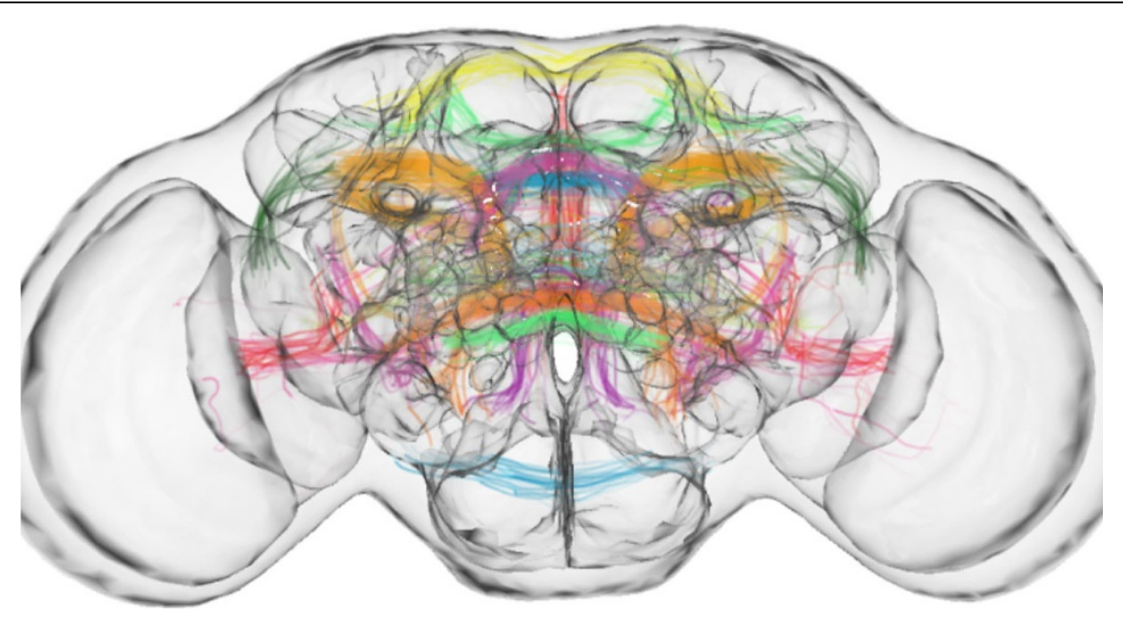

Figure 1 Numerous PNs tracts relaying sensory inputs - including olfactory, visual, auditory, and gustatory - to higher brain centers were discovered.

Correspondence: 0203126@narlabs.org.tw

National Center for High-Performance Computing, Taiwan, Republic of China

(c) 2015 Chuang This is an Open Access article distributed under the terms of the Creative Commons Attribution License (http:// creativecommons.org/licenses/by/4.0), which permits unrestricted use, distribution, and reproduction in any medium, provided the original work is properly cited. The Creative Commons Public Domain Dedication waiver (http://creativecommons.org/publicdomain/ zero/1.0/) applies to the data made available in this article, unless otherwise stated. 


\section{References}

1. Li CY, Chuang CC, Hua TT, Chen CC, Dickson BJ, Greenspan RJ, et al: A comprehensive wiring diagram of the protocerebral bridge for visual information processing in the Drosophila brain. Cell Reports 2013, 3(5):1739-1753.

2. Lee PC, Chuang CC, Chiang AS, Ching YT: High-throughput computer method for $3 \mathrm{~d}$ neuronal structure reconstruction from the image stack of the Drosophila brain and its applications. PLoS Computational Biology 2012, 8(9):e1002658.

3. Chiang AS, Lin CY, Chuang CC, Chang HM, Hsieh CH, Yeh CW, et al: Threedimensional reconstruction of brain-wide wiring networks in Drosophila at single-cell resolution. Current Biology 2011, 21(1):1-11.

doi:10.1186/1471-2202-16-S1-P35

Cite this article as: Chuang: A novel method to find out sensory neuron tracts in the Drosophila brain. BMC Neuroscience 2015 16(Suppl 1):P35.

\section{Submit your next manuscript to BioMed Central} and take full advantage of:

- Convenient online submission

- Thorough peer review

- No space constraints or color figure charges

- Immediate publication on acceptance

- Inclusion in PubMed, CAS, Scopus and Google Scholar

- Research which is freely available for redistribution

Submit your manuscript at www.biomedcentral.com/submit
(Ciomed Central 